\title{
Diel and seasonal changes in the macrozooplankton community of a tropical estuary in Northeastern Brazil
}

\author{
Tâmara de Almeida e Silva, Sigrid Neumann-Leitão, Ralf Schwamborn, \\ Lúcia Maria de Oliveira Gusmão \& Dilma Aguiar do Nascimento-Vieira
}

\begin{abstract}
Departamento de Oceanografia, Universidade Federal de Pernambuco. Cidade Universitária, 50670-901 Recife, Pernambuco, Brasil. E-mail: sigrid@terra.com.br
\end{abstract}

\begin{abstract}
Studies were carried out to assess the macrozooplankton small-scale temporal and spatial variability at three stations in three hours intervals, during 24 hours in July 1996 (rainy season) and December 1996 (dry season). A plankton net $300 \mu \mathrm{m}$ mesh size was hauled at surface during three minutes. Water samples for salinity, temperature, dissolved oxygen and $\mathrm{pH}$ were taken simultaneously with the zooplankton samples. Sixty-five macrozooplankton taxa were registered. Copepoda constituted the most common taxon and comprised $58 \%$ of the total zooplankton counts. Brachyuran zoeae, cirripedian larvae, Larvacea (Oikopleura dioica Fol, 1872), and Gastropoda veligers were abundant at some tidal cycles, mainly during the night. Species diversity average was

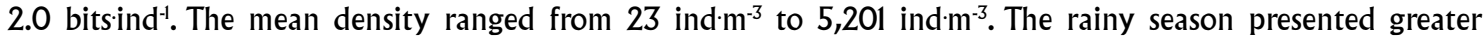
numerical abundance. A regular temporal zooplankton cycle was not observed. Instead, there was a large stochastic variation between samples.
\end{abstract}

KEY WORDS. Diurnal variation, estuary, planktonic fauna, tidal variation.

The Santa Cruz Channel (Pernambuco State, Brazil) is a mangrove area with complex hydrographic conditions (MederRos \& KJeRve 1993, Medeiros et al. 2001). It is the core of the Itamaracá estuarine system, one of the most intensively studied water bodies in Brazil (Paranaguá \& Eskinazi-LeÇa 1985, Neumann-Leitão 1995, Barros et al. 2000, Medeiros et al. 2001, Neumann-Leitão et al. 2001).

Zooplankton is an important intermediate component in estuarine food webs, acting as a trophic link between small particles (e.g. detritus and microalgae) and planktivorous fishes (MORGAN 1990). On the other hand, commercially important fish, shrimp and crab species produce larvae which are part of the macrozooplankton.

Knowledge of the variability of zooplankton communities (i.e. abundance and species composition) at different spatial and temporal scales is a prerequisite to understanding their dynamics. In estuaries, environmental conditions which are very variable in both time and space strongly affect the distribution of zooplankton species (DAUvin et al. 1998).

In spite of its great importance, relatively little work has been done on the zooplankton of mangrove habitats (ROBERTSON \& Blaber 1992). Even at the Santa Cruz Channel where different aspects of the zooplankton has been studied (SCHWAMBORN 1997, Porto Neto et al. 1999, Neumann-Leitão \& Schwamborn 2000, Neumann-Leitão et al. 2001, Shwamborn et al. 2001), no detailed studies were developed in the last 20 years on the main rivers flowing into the Channel.
As most estuaries, the Itamaracá estuarine ecosystem is exposed to multiple pressures from industrial pollution, domestic sewage discharge, urban expansion, land reclamation and fisheries (Medeiros et al. 2001).

The study was designed to yield quantitative data on macrozooplankton from the main polluted estuaries that drain into the Santa Cruz Channel and the area around the bridge in the channel which receives raw domestic sewage, to assess smallscale temporal and spatial variability. The results will enhance our understanding of small scale processes which may also be useful for monitoring pollution effects in tropical estuaries.

\section{MATERIAL AND METHODS}

The Santa Cruz Channel is a U-shaped estuarine channel $20 \mathrm{~km}$ long with two connections to the South Atlantic Ocean, located at $7^{\circ} 34^{\prime} 00^{\prime \prime}$ to $7^{\circ} 55^{\prime} 16^{\prime \prime} \mathrm{S}$ and $34^{\circ} 48^{\prime} 48^{\prime \prime}$ to $34^{\circ} 52^{\prime} 24^{\prime} \mathrm{W}$. From north to south the rivers Catuama, Carrapicho, Congo, Arataca, Botafogo, and Igarassú drain into the channel, the last two being the major freshwater sources (Medeiros \& KJerfve 1993) and most polluted. The Santa Cruz Channel separates Itamaracá Island from the mainland and is the central part of the Itamaracá Estuarine System (Medeiros \& KJERFVE 1993). Tides in this natural Channel are strongly semidiurnal and the mean tidal range varies between 1.0 and $1.8 \mathrm{~m}$ (spring 1.4-2.2 m, neap 0.5-1.1 m) with lower ranges near the hydrographic centre about $1.7 \mathrm{~km}$ north of Itapissuma Bridge 
(Medeiros \& KJerfve 1993). This system sustains $36 \mathrm{~km}^{2}$ of mangrove forests, dominated by Rhizophora mangle Linnaeus, 1753, Laguncularia racemosa C. F. Gaertner, 1788 and Avicennia spp. (Medeiros \& Kjerfve 1993, Barros et al. 2000). Dense crab populations inhabit the mangrove. Some crab species, such as Ucides cordatus (Linnaeus, 1763), Goniopsis cruentata (Latreille, 1802), and Cardisoma guanhumi Latreille, 1825, are of commercial importance. Molluscs, such as oysters - Crassostrea rhizophorae (Guilding, 1828) - are socio-economical important for many fisherwomen (BARRos et al. 2000).

Intensive 24-hour sampling was conducted simultaneously at three fixed stations during spring tide, at intervals of three hours, in the rainy season (July 1996), and in the dry season (December 1996). Stations were located at the Botafogo River inlet, in the middle of Santa Cruz Channel close to the bridge that connects the continent to Itamaracá Island and at the Igarassú River inlet (Fig. 1).

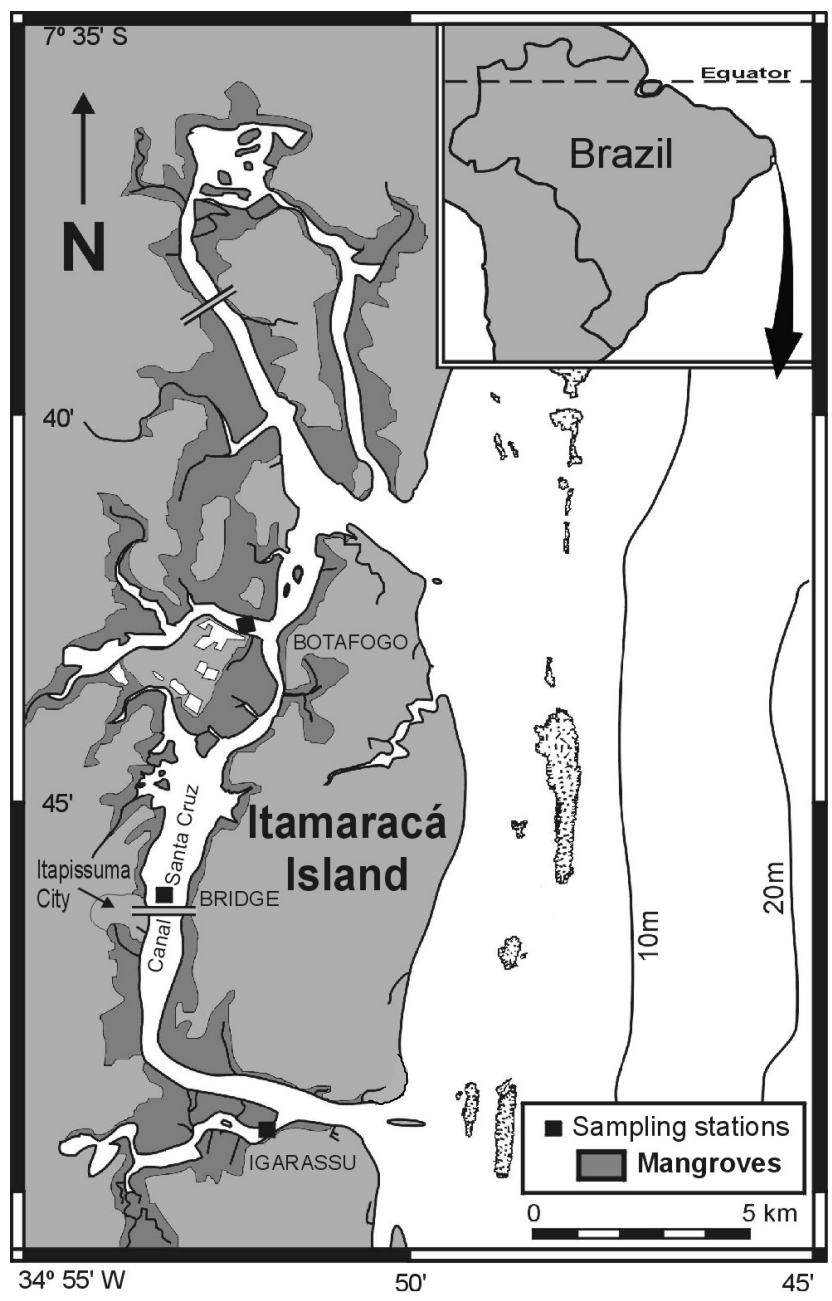

Figure 1. Map of the Itamaracá estuarine system, showing the Santa Cruz Channel and the position of sampling stations.
Hydrological data were collected at surface with a Nansen bottle. Water temperature was recorded with a reversion thermometer fixed to Nansen bottle, salinity was measured with the Mohr-Knudsen method and dissolved oxygen with the Winkler method (STRICKLAND \& PARSONS 1965).

Zooplankton was sampled with a plankton net with $300 \mu \mathrm{m}$ mesh size hauled horizontally for three minutes at subsurface at each station. A flowmeter (Hydrobios, Kiel) was fitted on the opening of each net used. Samples were preserved in a $4 \%$ buffered formaline/seawater solution. Plankton biomass was determined by wet weight (WW) according to OMORI \& IKEDA (1984). Macrozooplankton species were identified until the lowest taxonomic unit possible and taxon abundance (per cubic meter) counted under a stereomicroscope, based on $8 \mathrm{ml}$ sub-samples. Three sub-samples were taken with a Stempelpipette, after the sample was diluted to $500 \mathrm{ml}$ and gently homogenized.

Differences between seasons, stations, tides, night and day were tested for significance using non-parametric MannWhitney test (CONOver 1980).

The Shannon diversity index $\left(\mathrm{H}^{\prime}\right)$ was applied for the estimation of community diversity based on $\log _{2}$ (SHANNON 1948) and the evenness calculated according to PIELOU (1977). Samples cluster analysis on the sample-species data matrix was also performed using the Bray \& Curtis index after data standardization and $\log (\mathrm{x}+1)$ transformation (Ibanez 1976). The link method for the dendrogram was the Weighted Pair Group Method-Arithmetical Averages (WPGMA) (LEgENDRE \& LEgENDRE 1998). A symmetrical matrix of cophenetic dissimilarity value was produced to test the goodness of fit of the cluster analysis to the data (Rohlf \& SOKAL 1981).

\section{RESULTS}

Temperature, salinity and dissolved oxygen showed characteristic variation related to the semi-diurnal tidal cycle. Minimum and maximum values of these parameters are presented in table I. Water temperatures lacked horizontal gradients. Temperature always exceeded $25^{\circ} \mathrm{C}$, and reached $31^{\circ} \mathrm{C}$ during the day in the dry season. At Botafogo Station the temperature varied from $25.8^{\circ} \mathrm{C}(01: 00 \mathrm{~h})$ to $27.2^{\circ} \mathrm{C}(16: 00 \mathrm{~h})$ in the rainy season and from $29^{\circ} \mathrm{C}(04: 00 \mathrm{~h})$ to $31^{\circ} \mathrm{C}(13: 00$ and $16: 00 \mathrm{~h})$ in the dry season. At Bridge Station the temperature varied from $25^{\circ} \mathrm{C}(22: 00 \mathrm{~h})$ to $28.1^{\circ} \mathrm{C}(13: 00 \mathrm{~h})$ in the rainy season and from $29^{\circ} \mathrm{C}(22: 00 \mathrm{~h})$ to $31^{\circ} \mathrm{C}(13: 00 \mathrm{~h})$ in the dry season. At Igarassú Station the temperature varied from $25.8^{\circ} \mathrm{C}(01: 00 \mathrm{~h})$ to $27.2^{\circ} \mathrm{C}(13: 00 \mathrm{~h})$ in the rainy season and from $28.6^{\circ} \mathrm{C}(04: 00$ h) to $30.5^{\circ} \mathrm{C}(13: 00$ and $16: 00 \mathrm{~h})$ in the dry season.

The salinity at Botafogo Sation ranged between 17.4 and $30.69 \mathrm{psu}$ in the rainy season and from 23.53 to $33.69 \mathrm{psu}$ in the dry season. At Bridge Station salinity ranged between 25.3 and 26.38 psu in the rainy season and from 29.14 and 31.01 psu in the dry season. At Igarassú Station salinity varied from 22.34 to $33.65 \mathrm{psu}$ in the rainy season and from 24.06 to 35.56 psu in the dry season (Fig. 2). Overall salinity was lower at the rainy season. The Bridge Station showed the least variation.

Dissolved oxygen saturation in the rainy season varied from $55.42 \%$ (diurnal low tide - 10:00 h) to $115.15 \%$ (diurnal high tide $-16: 00 \mathrm{~h}$ ) both at Igarassú station (Fig. 2). In the dry season dissolved oxygen saturation ranged from $45.89 \%$ (diurnal low tide $-10: 00 \mathrm{~h}$ ) to $133.26 \%$ (diurnal high tide $-16: 00$

Revista Brasileira de Zoologia 20 (3): 439-446, setembro 2003 

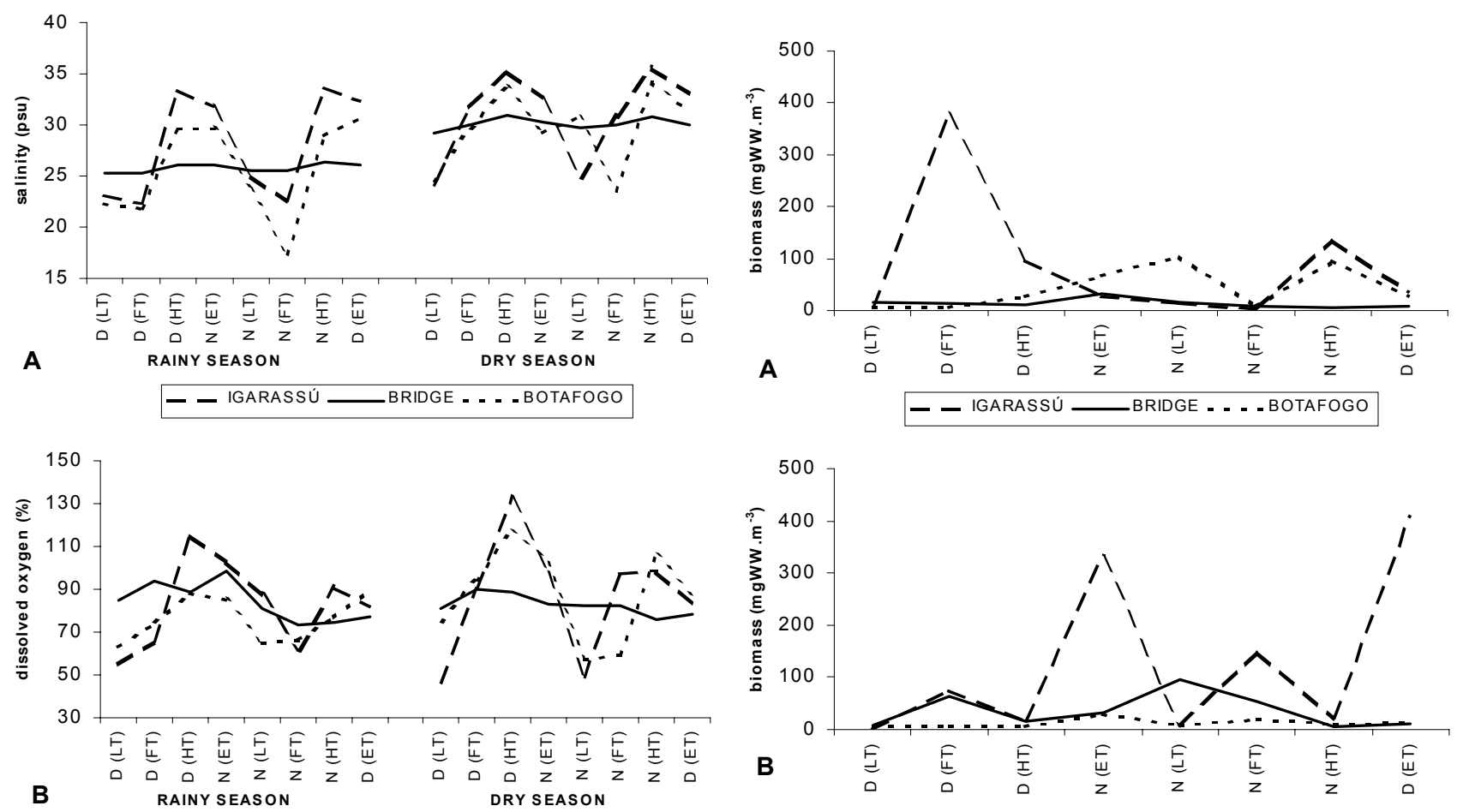

Figure 2. Distribution of the salinity (A) and dissolved oxygen saturation (B) at three stations at Santa Cruz Channel area, Pernambuco, Brazil, during 24 hours in July 1996 (rainy season) and December 1996 (dry season). (D ) Day, (N) night, (LT) low tide, (FT) flood, (HT) high tide, (ET) ebb.

h) both at Igarassú Station. Only $12.5 \%$ of the samples had more than $100 \%$ and approximately $21 \%$ of the samples showed less than $60 \%$ saturation.

Plankton biomass varied in relation to the tidal cycle. In the rainy season biomass ranged from $1.4 \mathrm{mg} \cdot \mathrm{m}^{-3}(01: 00 \mathrm{~h})$ to $375.7 \mathrm{mg} \cdot \mathrm{m}^{-3}(13: 00 \mathrm{~h})$ both during flood tide at the Igarassú Station (Tab. I, Fig. 3), with an average biomass of $47.4 \mathrm{mg} \cdot \mathrm{m}^{-3}$. In the dry season biomass ranged from $0.92 \mathrm{mg}^{-3}$ (diurnal low tide $-10: 00 \mathrm{~h}$ ) to $408.19 \mathrm{mg} \cdot \mathrm{m}^{-3}$ (diurnal ebb tide 07:00 h) both at the Igarassú Station (Tab. I, Fig. 3), with an average biomass of $57.9 \mathrm{mg} \cdot \mathrm{m}^{-3}$.

Sixty-five zooplankton taxa were identified (Tab. II). Copepods dominated most samples although meroplankton larvae dominated in some night samples, mainly at low tide and during the dry season. The most abundant taxa were Acartia lilljeborgi Giesbrecht, 1889 in the adult stage $(31.2 \%$ of the total zooplankton), brachyuran zoeae and megalopae (21\%), Oithona oswaldocruzi Oliveira, 1945 (10.7\%) and Pseudodiaptomus marshi Wright, 1936 (8.6\%). Calanopia americana F. Dahl, 1894, Pseudodiaptomus richardi (F. Dahl, 1894), Temora turbinata Dana, 1849, Oikopleura dioica Fol, 1872, protozoeae Lucifer faxoni Borraidaile, 1915 and gastropod larvae were important in some samples.

The most frequent taxa were Acartia lilljeborgi (93.8\% of the samples), Oithona oswaldocruzi (87.5\%), zoeae and megalopae of Brachyura (85.4\%), Pseudodiaptomus marshi (79.2\%),

Figure 3. Wet weight (WW) plankton biomass at three stations at Santa Cruz Channel area, Pernambuco, Brazil, during 24 hours in July 1996 (rainy season) (A) and December 1996 (dry season) (B). (D) Day, (N) night, (LT) low tide, (FT) flood, (HT) high tide, (ET) ebb.

nauplii of Balanus spp. (60.4\%) and Oikopleura dioica (56.3\%).

Minimum abundance ( 23 ind $\mathrm{m}^{-3}$ ) was registered at Igarassú Station (flood tide during dry season), and the maximum abundance $\left(5,201\right.$ ind $\left.\mathrm{m}^{-3}\right)$ registered at Botafogo Station (high tide during rainy season) (Tab. I, Fig. 4). Average abundance for both seasons was 1,464 ind $\mathrm{m}^{-3}$ (Botafogo Station), 366 ind $\mathrm{m}^{-3}$ (Bridge Station) and 1,213 ind $\mathrm{m}^{-3}$ (Igarassú Station).

During the rainy season, two peaks were registered for the Botafogo Station both dominated by Acartia lilljeborgi, at diurnal $\left(4,336\right.$ ind $\left.\mathrm{m}^{-3}\right)$ and nocturnal $\left(915 \mathrm{ind} \cdot \mathrm{m}^{-3}\right)$ high tide; average abundance to this station was $1,876 \mathrm{ind} \cdot \mathrm{m}^{-3}$. The Bridge station had only one peak at nocturnal ebb tide with Acartia lilljeborgi being most abundant $\left(834\right.$ ind $\mathrm{m}^{-3}$ ); average abundance was 476 ind $\mathrm{m}^{-3}$. The Igarassú Station presented also two peaks at this season, one at low tide, where the most abundant species were Calanopia americana $\left(1,390 \mathrm{ind}^{-3}\right)$ and Pseudodoiaptomus marshi $\left(1,109\right.$ ind $\left.\mathrm{m}^{-3}\right)$ and the other one at high tide with $P$. richardi $\left(1,571\right.$ ind $\left.\mathrm{m}^{-3}\right)$ as most abundant, both at night samplings; average abundance to Igarassú Station was 1,004 ind $\mathrm{m}^{-3}$.

At the dry season one peak was observed for the Botafogo Station, at nocturnal low tide with brachyuran zoeae attaining 3,480 ind. $\mathrm{m}^{-3}$, average abundance in this station was 1,178 ind $\mathrm{m}^{3}$. At the Bridge Station, two small peaks were registered at diurnal and nocturnal high tide with Oithona oswaldocruzi 

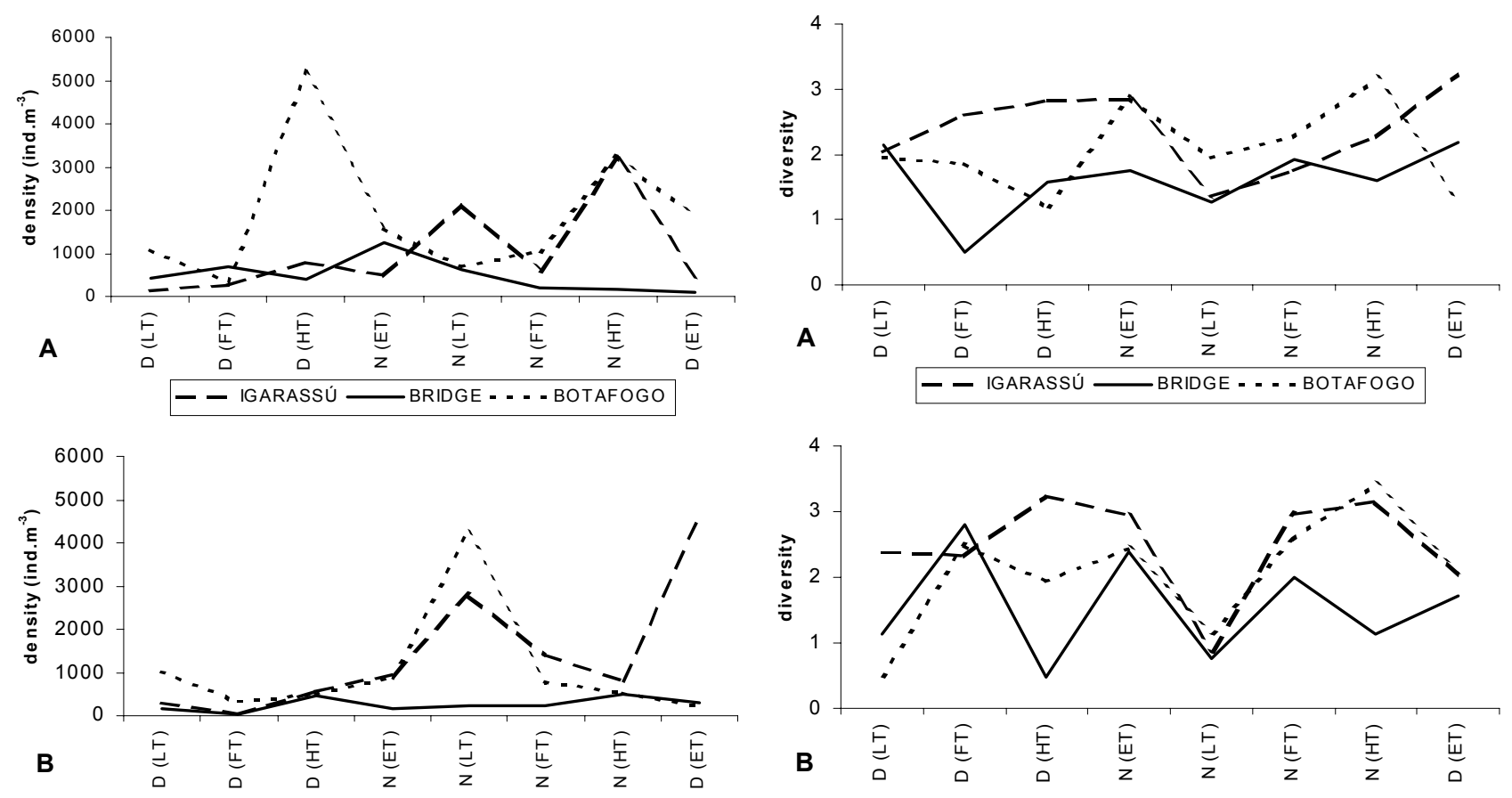

Figure 4. Zooplankton numerical abundance at three stations at Santa Cruz Channel area, Pernambuco, Brazil, during 24 hours in July 1996 (rainy season) (A) and December 1996 (dry season) (B).

(D) Day, (N) night, (LT) low tide, (FT) flood, (HT) high tide, (ET) ebb.

Figure 5. Zooplankton species diversity at three stations at Santa Cruz Channel area, Pernambuco, Brazil, during 24 hours in July 1996 (rainy season) (A) and December 1996 (dry season) (B). (D) Day, (N) night, (LT) low tide, (FT) flood, (HT) high tide, (ET) ebb.

Table I. Minimum (MIN) and maximum (MAX) data of the main parameters at three stations in the Santa Cruz Channel area, Pernambuco, Brazil, during 24 hours in July 1996 (rainy season) and December 1996 (dry season).

\begin{tabular}{|c|c|c|c|c|c|c|c|c|c|c|c|c|}
\hline \multirow{3}{*}{$\begin{array}{c}\text { Stations } \\
\text { Seasons } \\
\text { Parameters }\end{array}$} & \multicolumn{4}{|c|}{ Botafogo } & \multicolumn{4}{|c|}{ Bridge } & \multicolumn{4}{|c|}{ Igarassú } \\
\hline & \multicolumn{2}{|c|}{ Rainy } & \multicolumn{2}{|r|}{ Dry } & \multicolumn{2}{|c|}{ Rainy } & \multicolumn{2}{|c|}{ Dry } & \multicolumn{2}{|c|}{ Rainy } & \multicolumn{2}{|c|}{ Dry } \\
\hline & Min & Max & Min & Max & Min & Max & Min & Max & Min & Max & Min & Max \\
\hline Temperature $\left({ }^{\circ} \mathrm{C}\right)$ & 25.8 & 27.2 & 29 & 31 & 25 & 28.1 & 29 & 31 & 25.8 & 27.2 & 28.6 & 30.5 \\
\hline Salinity (psu) & 17.36 & 30.69 & 23.53 & 33.69 & 25.3 & 26.38 & 29.14 & 31.01 & 22.34 & 33.65 & 24.06 & 35.56 \\
\hline Dissolved oxygen $\left(\mathrm{ml}^{. \mathrm{I}^{-1}}\right)$ & 3.09 & 4.26 & 2.78 & 5.1 & 3.62 & 4.36 & 3.42 & 3.95 & 2.71 & 5.32 & 2.12 & 5.77 \\
\hline Dissolved oxygen saturation (\%) & 62.8 & 89.68 & 59.15 & 117.78 & 72.98 & 98.16 & 75.83 & 89.77 & 55.42 & 115.15 & 45.89 & 133.26 \\
\hline Biomass (mgWW. $\mathrm{m}^{-3}$ ) & 5.65 & 104.52 & 4.24 & 29.66 & 4.24 & 31.07 & 4.24 & 94.63 & 1.42 & 375.71 & 0.92 & 408.19 \\
\hline Density (ind. $\mathrm{m}^{-3}$ ) & 316 & 5,201 & 317 & 4,228 & 191 & 1,244 & 30 & 487 & 131 & 3,174 & 23 & 4,565 \\
\hline Diversity & 1.19 & 3.17 & 0.50 & 3.41 & 0.51 & 2.18 & 0.47 & 2.79 & 1.35 & 3.24 & 0.88 & 3.25 \\
\hline Evenness & 0.24 & 0.67 & 0.26 & 0.80 & 0.18 & 0.69 & 0.16 & 0.88 & 0.35 & 0.78 & 0.22 & 0.89 \\
\hline
\end{tabular}

with 410 ind $\mathrm{m}^{-3}$ and 396 ind $\mathrm{m}^{-3}$, respectively; average abundance was 487 ind $\mathrm{m}^{-3}$. At the Igarussu Station, two peaks were registered, caused by a high abundance of $O$. oswaldocruzi one at nocturnal low tide $\left(2,365\right.$ ind $\left.\mathrm{m}^{-3}\right)$ and the other at diurnal ebb tide $\left(2,908\right.$ ind $\left.^{-3}\right)$, with general average abundance of 1,422 ind $\mathrm{m}^{-3}$.
Average species diversity was 2.01 during the rainy season and 2.03 during the dry season, values ranging from low (0.5) to high values (3.25) (Fig. 5). Minimum and maximum values for each station were 0.50 and 3.41 (Botafogo Station), 0.47 and 2.79 (Bridge Station), and 0.88 and 3.25 (Igarassú Station) (Tab. I). Average evenness was 0.55 to the rainy season

Revista Brasileira de Zoologia 20 (3): 439-446, setembro 2003 
Table II. Zooplankton composition at three stations in the Santa Cruz Channel area, Pernambuco, Brazil, during 24 hours in July 1996 (rainy season) and December 1996 (dry season).

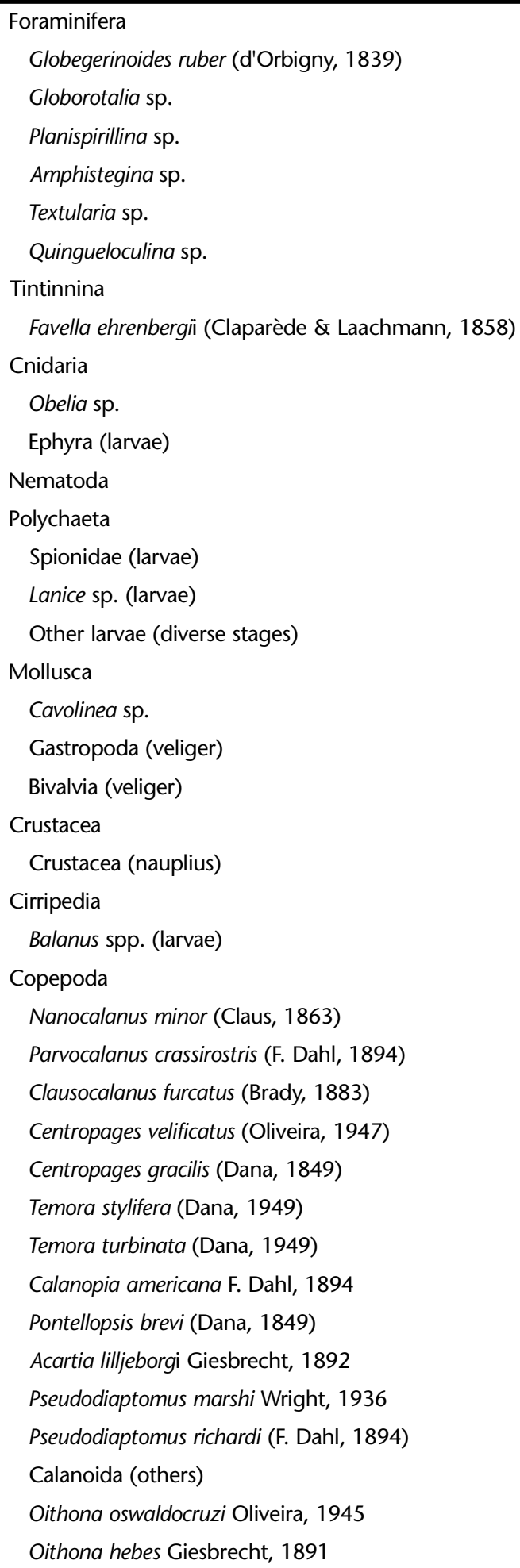

Oncaea media Giesbrecht, 1891

Corycaeus (Onychocorycaeus) giesbrechti F. Dahl, 1894

Tisbes sp.

Hemicyclops thalassius Vervoort \& Ramirez, 1966

Euterpina acutifrons (Dana, 1852)

Tigriopus sp.

Caligus sp.

Ostracoda

Conchoecia sp.

Mysidacea

Amphipoda

Synopia sp.

Turbergella sp.

Isopoda (larvae Epicaridae)

Cumacea

Euphausiacea

Decapoda

Lucifer (protozoea)

Lucifer (mysis)

Lucifer faxoni Borraidele, 1915

Acetes sp.

Panaeus sp. (larvae)

Caridea (larvae)

Paleomonidae (larvae)

Porcellanidae (zoeae)

Brachyura (zoeae and megalopa)

Callianassea sp.

Alpheidae (larvae)

Paguridae (larvae)

Processidae (larvae)

Albunea sp. (larvae)

Bryozoa

Membranipora sp. (larvae)

Chaetognatha

Sagitta friderici Ritter-Zahóny, 1910

Echinodermata (pluteus)

Larvacea

Oikopleura dioica Fol, 1872

Oikopleura rufescens Fol, 1872

Ascidiacea (larvae)

Pisces (egg and larvae) 
and 0.52 to the dry season, with minimum of 0.16 and maximum of 0.89 for both in the dry season (Fig. 6). Minimum and maximum evenness values for each station were 0.24 and 0.80 (Botafogo Station), 0.16 and 0.88 (Bridge Station), and 0.22 and 0.89 (Igarassú Station) (Tab. I).
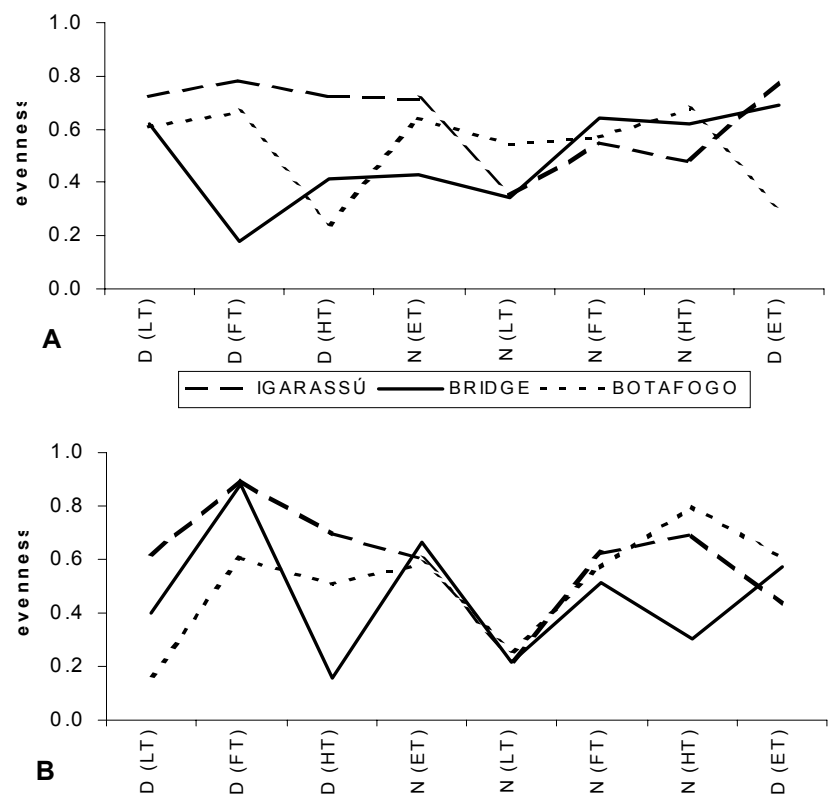

Figure 6. Zooplankton eveness at three stations at Santa Cruz Channel area, Pernambuco, Brazil, during 24 hours in July 1996 (rainy season) (A) and December 1996 (dry season) (B). (D) Day, (N) night, (LT) low tide, (FT) flood, (HT) high tide, (ET) ebb.

Differences in total abundance between day and night samples was significative to Igarassú (Mann-Whitney test, $\mathrm{p}=$ 0.01) and Botafogo (Mann-Whitney test, $\mathrm{p}=0.04$ ) Stations. Significative differences were also found between the rainy and dry seasons (Mann-Whitney test, $\mathrm{p}=0.04$ ); between the Igarassú and Bridge Stations (Mann-Whitney test, $\mathrm{p}=0.01$ ), and the Botafogo and Bridge Stations (Mann-Whitney test, $\mathrm{p}=0.01$ ). No difference was found between Igarassú and Botafogo Stations (Mann-Whitney test, $\mathrm{p}=0.18$ ).

The cophenetic analysis presented a $r=0.83$ indicating a good fit of the data. Samples clustering produced three groups, indicating the importance of seasonal changes: Group 1) formed by the flood and low tide samples from Igarassú and Botafogo Stations of both rainy and dry seasons. Group 2) characterised by all samples from the dry season except for those in group 1. Group 3) characterised by all samples from the rainy season, except for those in group 1 (Fig. 7).

\section{DISCUSSION}

At the Santa Cruz channel greatest variation of salinity was registered during the rainy season, mainly at the Botafogo Station. According to Medeiros et al. (2001), seasonal differences in rainfall and freshwater runoff are significant at Santa

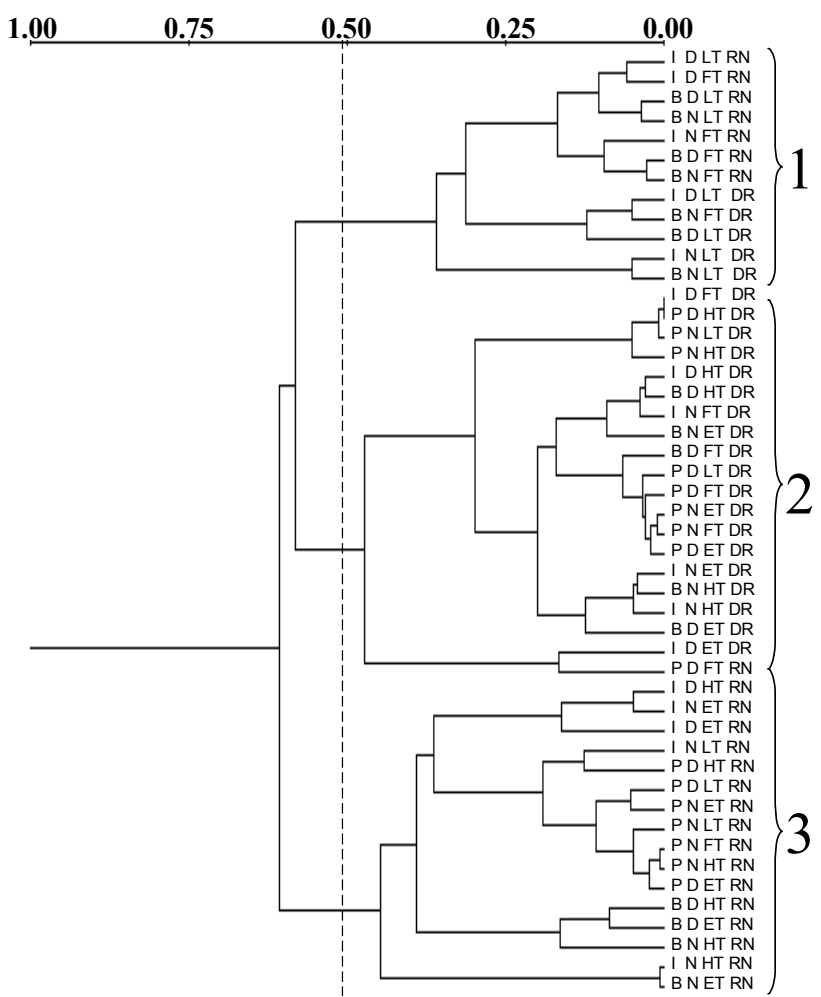

Figure 7. Dendrogram resulting from the Bray \& Curtis analysis of 48 zooplankton samples at Santa Cruz Channel area, Pernambuco, Brazil, during 24 hours in July 1996 (rainy season = RN) and December 1996 (dry season = DR). (D) Day, (N) night, (LT) low tide, (FT) flood, (HT) high tide, (ET) ebb, (I) Igarassú, (B) Botafogo, (P) Bridge.

Cruz Channel, with total average river discharge varying between $55.9 \mathrm{~m}^{3} \mathrm{~s}^{-1}$ at the peak of the rainy season and $0.8 \mathrm{~m}^{3} \cdot \mathrm{s}^{-1}$ at the peak of dry season. The cluster of samples showed that prominent differences occurred between dry and rainy seasons.

Principal dominant parameters in the Santa Cruz ecosystem are salinity and dissolved oxygen, which are controlled by the tides. According to Medeiros \& KJeRFve (1993), overall salinity in the Santa Cruz area is lower in the rainy ( $27 \mathrm{psu}$ ) than in the dry season (34 psu). During the dry season, hypersaline conditions ( $37 \mathrm{psu}$ ) at both entrances of Santa Cruz Channel are due to evaporation, evapotranspiration by mangroves, and reduced flow from the rivers (Medeiros et al. 2001). The estuary is well mixed and salinity differences from surface to bottom are less than 1 psu. During the rainy season, the northern channel tends to be stratified at neap tide. Specially at the confluence of the Botafogo river, large freshwater discharge and reduced tidal mixing energy favour stratification with a surface to bottom salinity gradient of 12 psu (Medeiros et al. 2001).

According to the classification of estuarine plankton given by BolTovsкoY $(1981,1999)$, the macrozooplankton community collected in the Santa Cruz area may be defined as an 
euryhaline marine assemblage. It was largely dominated by coastal neritic species including the calanoid copepods Acartia lilljeborgi, Calanopia americana and the appendicularian Oikopleura dioica, together with estuarine mangrove species Pseudodiaptomus marshi, P. richardi, Oithona oswaldocruzi and brachyuran larvae. This composition is very similar to the results from other northeastern Brazilian estuaries (NeumANNLEITÃo 1995).

The decrease in zooplankton diversity with decreasing salinity indicated the major role of this parameter in the occurrence and distribution of euryhaline species, mainly sampled during high tide, like the copepods.

Within the Santa Cruz stations, temporal variations in the species composition and densities were mainly due to the semi-diurnal tidal cycle. For most species, higher densities were observed around high tide, when the intrusion of marine waters is maximal, while just a few species (e.g. Brachyuran larvae, Oithona oswaldocruzi and Pseudodiaptomus richardi) were more abundant around low tide. The amplitude of such variations over one tidal cycle were quite variable among taxa and varied between two and more than 50 -fold. The predominant role of instantaneous tidal currents in zooplankton variability within tidal estuaries has also been reported by several authors (Lee \& Mcalice 1979, Cronin \& Forward 1986, Schlacher \& Wooddridge 1995, Dauvin et al. 1998, Neumann-Leitão \& MatsumURA-TUNDISI 1998, among others).

The highest densities of brachyuran larvae around low tide could be related to the high biomass of adult crabs in the mangroves existing along the Channel and riverside (Coelho 2000). Taxonomic composition, distribution and food web dynamics of brachyuran zoeae presented by SCHWAMBORN (1997) and SCHWAMBORN et al. (1999a) support the assumption that high abundance of this larvae off Itamaracá are due to export from mangroves. Medeiros et al. (2001) mention an overall tidal export from the Santa Cruz inlets to the adjacent shelf of $1.5 \times 10^{8}$ zoeae per day. Since decapod larvae and copepods are an important food for many fish species (VASCONCELos et al. 1984, Morgan 1990, SAUTOUR et al. 1996), the export of these groups from mangroves to the shelf means an important input to marine food webs.

Besides tidal changes, short-term variations in the zooplankton community also resulted from diurnal changes. The calanoid Calanopia americana which is benthic during the day (BJÖRNBERG 1981) attained high densities in the plankton during the night at Igarassú Station.

At the Itamaracá estuary, Acartia lilljeborgi had an important role and this may be related to the high amount of detritus occurring in the area that is consumed by this species, as has been demonstrated through stable isotope measurements and feeding experiments performed in the laboratory and in situ (SCHWAMBorn 1997, SCHWAmborn et al. 1999b).

The zooplankton community decreased in density and diversity in the last twenty years when comparing with data from Paranaguá \& Nascimento-Vieira (1984) and Paranaguá \& EsKINAZI-LEÇA (1985), affecting the fisheries production in the area.

It can be concluded that the main difference between the dry and the rainy seasons in the zooplankton community was in composition. The larvae of several taxa, mainly benthic decapods were abundant in the dry season, while calanoid copepods dominated in the rainy season. In general, night samples presented higher density of decapod larvae in the dry season and higher density of copepods at the rainy season. No differences were observed in composition between Igarassú and Botafogo Stations. Bridge Station presented lower zooplankton density and diversity, probably due to the decrease in the magrove area and higher pollution from Itapissuma Town.

\section{REFERENCES}

Barros, H.M.; E. Eskinazi-Leça; S.J. Macedo \& T. Lima. 2000. Gerenciamento participativo de estuários e manguezais. Recife, Editora Universitária, Pernambuco, 252p.

BJöRnBERG, T.K.S. 1981. Copepoda, p. 587-679. In: D. BoltovskoY (Ed.). Atlas del zooplancton del Atlántico Sudoccidental y métodos de trabajos con el zooplancton marino. Mar del Plata, INIDEP, 936p.

Boltovsкoy, D. 1981. Atlas del zooplancton del Atlántico Sudoccidental y métodos de trabajos con el zooplancton marino. Mar del Plata, INIDEP, 936p.

. 1999. South Atlantic Zooplankton. Leiden, Backhuys, $1706 \mathrm{p}$.

Coelho, P.A. 2000. Carcinofauna, p. 119-142. In: H.M. Barros; E. EskinaZi-LeÇA; S.J. Macedo \& T. Lima (Eds). Gerenciamento participativo de estuários e manguezais. Recife, Editora Universitária, 252p.

Conover, W.J. 1980. Practical Nonparametric Statistics. New York, Wiley, 493p.

Cronin, T.W. \& R.B. Forward Jr. 1986. Vertical migration cycles of crab larvae and their role in crab dispersal. Bulletin of Marine Science, Miami, 39: 192-201.

Dauvin, J.C.; E. ThiÉBAut \& Z. WANG. 1998. Short term changes in the mesozooplanktonic community in the Seine ROFI (Region of Freshwater Influence) (eastern English Channel). Journal of Plankton Research, Oxford, 20: 1145-1167.

IBANEZ, F. 1976. Contribution à l'analyse mathématique des évènements en ecologie planctonique. Bulletin Institute Océanographique, Monaco, 72: 1-96.

Lee, W.Y. \& B.J. Mcalice. 1979. Sampling variability of marine zooplankton in a tidal estuary. Estuarine, Coastal and Shelf Science, London, 8: 565-582.

Legendre, L. \& P. Legendre. 1998. Numerical Ecology. Amsterdam, Elsevier, 853p.

Medeiros, C.Q. \& B. KJerfve. 1993. Hydrology of a tropical estuarine system: Itamaracá, Brazil. Estuarine, Coastal and Shelf Science, London, 36: 495-515.

Medeiros, C.; B. KJerfve; M. Araújo \& S. Neumann-Leitão. 2001. The Itamaracá Estuarine Ecosystem, Brazil, p.71-81. In: U. Seelinger, B. \& KJerfve (Eds.). Ecological Studies, 144. Coastal Marine Ecosystems of Latin America, Berlin, Springer-Verlag, 360p.

Morgan, S.G. 1990. Impact of planktivorous fishes on dispersal, hatching, and morphology of estuarine crab larvae. Ecology, Durham, 71: 1639-1652.

Neumann-Leitão, S. 1995. Resenha literária sobre zooplâncton estuarino no Brasil. Trabalhos Oceanográficos da Universidade Federal de Pernambuco, Recife, 23: 25-53.

Neumann-Leitão, S. \& T. Matsumura-Tundisi. 1998. Dynamics of a perturbed Estuarine Zooplanktonic Community: Port of Suape, PE, Brazil. Verhandlungen der Internationale

Revista Brasileira de Zoologia 20 (3): 439-446, setembro 2003 
Vereinigung für Limnologie, Stuttgart, 26: 1981-1988.

Neumann-Leitão, S. \& R. Schwamborn. 2000. Interações tróficas no Canal de Santa Cruz, p.163-180. In: H.M. BARRos; E. EsKINAZI-LEÇA; S.J. MACEDO \& T. LIMA (Eds). Gerenciamento participativo de estuários e manguezais. Recife, Editora Universitária, $252 p$.

Neumann-Leitão, S.; R. Schwamborn; S.J. Macedo; C. Medeiros; M.L. Koening; M.J.F. Montes; F.A.N. FeItosa \& L.M.O. Gusmão. 2001. Plankton Dynamics at Itamaracá Mangrove Estuarine System, Pernambuco, Brazil, p. 435-445. In: Y. VILlacampa; C.A. Brebita \& J.L. Usó (Eds). Ecosystems and Sustainable Development III. Southampton, Witt Press, 824p.

OMORI, M. \& T. IKEDA. 1984. Methods in marine zooplankton ecology. New York, Wiley, 332p.

Paranaguá, M.N. \& D.A. Nascimento-Vieira. 1984. Estudo ecológico da região de Itamaracá, Pernambuco-Brasil. 25. Zooplâncton do Rio Botafogo. Trabalhos Oceanográficos da Universidade Federal de Pernambuco, Recife, 18: 193-206.

Paranaguá, M.N. \& E. Eskinazi-Leça. 1985. Ecology of a northern tropical estuary in Brazil and technological perspectives in fishculture, p.595-614. In: A. YÁnez-Arincibia (Ed.). Fish community ecology in estuarine and coastal lagoons: Towards an ecosystem integration. Mexico, UNAM Press. $653 p$.

Pielou, E.C. 1977. Mathematical ecology. New York, Wiley, 385p.

Porto Neto, F.F.; S. Neumann-Leitão; L.M.O. Gusmão; D.A. NASCIMENTo-Vieira; A.P. Silva \& T.A. Silva. 1999. Variação sazonal e nictemeral do zooplâncton no canal de Santa Cruz, Itamaracá, Pernambuco, Brasil. Trabalhos Oceanográficos da Universidade Federal de Pernambuco, Recife, 27: 43-58.

Robertson, A.I. \& S.J.M. Blaber. 1992. Plankton, epibenthos, and fish communities, p.173-224. In: A.I. RoberTson \& D.M. AlONGI (Eds). Tropical mangrove ecosystems. Coastal and Estuarine Studies. 41. Washington, American Geophysical Union, 329p.

Rohl, F.J. \& R.R. SokAL. 1981. Comparing numerical taxonomic studies. Systematic Zoology, London, 30: 459-490.
Sautour, B.; F. Artigas; A. Herbland \& P. Laborde. 1996. Zooplankton grazing impact in the plume of dilution of the Gironde estuary (France) prior to the spring bloom. Journal of Plankton Research, Oxford, 18: 835-853.

SCHLACHER, T.A. \& T.H. Wooddridge. 1995. Small-scale distribution and variability of demersal zooplankton in a shallow, temperate estuary: tidal and depth effects on species-specific heterogeneity. Cahiers de Biologie Marineo, Paris, 36: 211227.

SCHWAMBORN, R. 1997. The influence of mangroves on community structure and nutrition of macrozooplankton in northeast Brazil. Zentrum für Marine Tropenökologie Contribution, Bremen, Alemanha, 4: 1-77.

Schwamborn, R.; W. Ekau; A.P. Silva; T.A. Silva \& U. Saint-Paul. 1999a. The contribution of estuarine decapod larvae to marine macrozooplankton communities in Northeast Brazil. Archive of Fishery and Marine Research, Jena, 47: 167182.

Schwamborn, R.; W. Ekau; M. Voss \& U. Saint-Paul. 1999b. Stable isotope composition of particulate organic matter and zooplankton in Northeast Brazilian shelf waters. Archive of Fishery and Marine Research, Jena, 47: 201-210.

Schwamborn, R.; S. Neumann-Leitão; A.P. Silva; T.A. Silva; W. Ekau $\&$ U. SaInt-Paul. 2001. Distribution and dispersion of decapod crustacean larvae and other zooplankton in the Itamaracá estuarine system, Brazil. Tropical Oceanography, Recife, 29 (1): 21-40.

SHANNON, C.E. 1948. A mathematical theory of communication. Bell System Technical Journal, San Diego, California, 27: 379-423.

Strickland, J.D.H. \& T.R. Parsons. 1965. A manual of seawater analysis. Bulletin Fisheries Research Board of Canada, Ottawa, 125: 1-205.

Vasconcelos, A.L.; D.S. Guedes; E.M.B. Galiza \& S. Azevedo-Araújo. 1984. Estudo ecológico da região de Itamaracá-Pernambuco-Brasil. XXVII. Hábitos alimentares de alguns peixes estuarinos. Trabalhos Oceanográficos da Universidade Federal de Pernambuco, Recife, 18: 231-260.

Received in 13.II.2003; accepted in 13.VIII.2003. 